\title{
Buildup of microbial biomass during deep winter mixing in a Mediterranean warm-core eddy
}

\author{
Tamar Zohary ${ }^{1, * * *}$, Stephen Brenner ${ }^{2}$, Michael D. Krom ${ }^{3}$, Dror L. Angel ${ }^{4}$, \\ Nurit Kress ${ }^{2}$, William K. W. Li $^{5}$, Amir Neori ${ }^{4}$, Yosef Z. Yacobi ${ }^{1}$ \\ ${ }^{1}$ Israel Oceanographic and Limnological Research Ltd. (IOLR), Kinneret Limnological Laboratory, Box 345, Tiberias 14102, Israel \\ ${ }^{2}$ IOLR, National Institute of Oceanography, Box 8030, Haifa 31080, Israel \\ ${ }^{3}$ Department of Earth Sciences, Leeds University, Leeds LS2 9JT, United Kingdom \\ ${ }^{4}$ IOLR, National Center for Mariculture, Box 1212, Eilat 88112, Israel \\ ${ }^{5}$ Bedford Institute of Oceanography, Box 1006, Dartmouth, Nova Scotia B2Y 4A2, Canada
}

\begin{abstract}
The Cyprus Eddy, a warm-core eddy southeast of Cyprus, was sampled towards the end of an exceptionally cold winter in early March 1992, within $4 \mathrm{~d}$ of a storm and within $24 \mathrm{~h}$ of an intrusion of cold air. Depth profiles of temperature, salinity and dissolved nutrients showed an active deep mixed layer from the surface to ca $500 \mathrm{~m}$ at the core of the eddy, while at the eddy boundaries the mixed layer extended only to $150 \mathrm{~m}$. Microbial populations were evenly distributed over the entire upper $500 \mathrm{~m}$ at the core station, as indicated by chlorophyl! and high performance liquid chromatography (HPLC)-determined pigment composition, by flow-cytometric analysis of the ultraphytoplankton, by direct counts of $4^{\prime}, 6$-diamidino-2-phenylindole (DAPI)-stained bacteria and ${ }^{3} \mathrm{H}$-thymidine measurements of bacterial activity. As far as we know, this is the first detailed description of the microbial populations in a warm-core eddy during the bloom season. The integrated water column chlorophyll content, $59 \mathrm{mg} \mathrm{m}^{-2}$ at the core and $45.5 \mathrm{mg} \mathrm{m}^{-2}$ at the boundary, was more than double the typica] late autumn values, suggesting a bloom was occurring. Noticeably, this bloom was not delayed until the establishment of summer stratification as has been observed previously in warm-core eddies. While theoretical considerations based on the calculated critical depth at the core of about $300 \mathrm{~m}$ suggested that a bloom should not have occurred, our data jointly with previous data from the Cyprus Eddy support the hypothesis that interim periods of quiescence between mixing events enable bloom development even when the mixing depth is greater than the critical depth. Added nutrients and dilution of grazers, both resulting from the deep mixing, probably contributed jointly to the enhanced productivity. Based on phytoplankton light-shade adaptation features and cellular chlorophyll fluorescence per cell, we calculated that the rate of vertical mixing in the core was at least $30 \mathrm{~m} \mathrm{~h}^{-1}$
\end{abstract}

KEY WORDS: Eastern Mediterranean - Warm-core eddy - Phytoplankton bloom - Vertical mixing rate Critical depth $\cdot$ Light-shade adaptation

\section{INTRODUCTION}

Mesoscale eddies have been recognized and studied as potentially important oceanographic features over the past 15 to 20 уг. Recent physical and ecosystem modeling attempts (Robinson 1983, Robinson \& Golnaraghi 1993, Malanotte-Rizzoli et al. 1996) have pro-

\footnotetext{
·E-mail: tamarz@inter.net.il

- Order of author names alphabetical, except for first 3 names
}

vided new insights into the role these eddies play in the dynamics and functioning of the Eastern Mediterranean Sea. Cold-core eddies are widely recognized as important sources of nutrients for new production, and within the oligotrophic Mediterranean 'desert' were labeled by Malanotte-Rizzoli (pers. comm.) as 'oases' of primary production. During the 1980s it was shown that cores of warm-core eddies also constitute areas of enhanced productivity as a result of deep winter mixing (Tranter et al. 1980, Bradford et al. 1982, Jenkins 1988). 
A quasi stationary, persistent warm-core eddy (or more accurately, sequence of eddies), known as the Cyprus Eddy (Fig. 1), was identified south of Cyprus in the Levantine basin of the Eastern Mediterranean (Robinson et al. 1987, Brenner 1989). The eddies are thought to form as a result of the interaction between the Mid-Mediterranean Jet and the Erastothenes Seamount (Brenner 1989), although results from recent numerical simulations indicate that the eddy may originate as an anticyclonic meander of the shelf break frontal system (Brenner 1997). Each individual eddy has a lifetime of 2 to 3 yr before it is replaced (Brenner 1993).

Krom et al. $(1992,1993)$ examined the seasonal dynamics of nutrients and chlorophyll concentrations in this eddy and reported that a phytoplankton bloom occurred following deep winter mixing, as manifested by elevated chlorophyll content. In this study we sampled the Cyprus Eddy in late winter to characterize and examine in detail the nature of the phytoplankton and bacterial populations during this bloom period. Of particular interest was a previous observation by Krom ct al. (1992) that in winter (mid-February 1989) in the

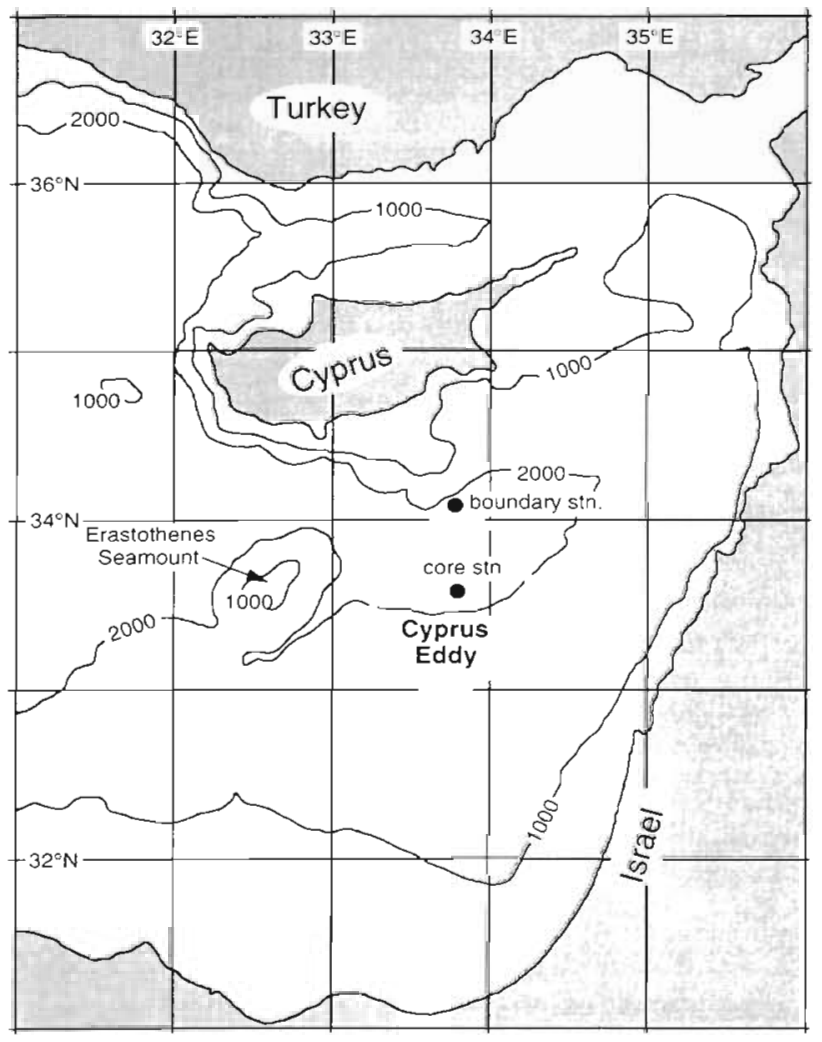

Fig. 1 Map of the eastern region of the Mediterranean Sea, showing the location of the Cyprus Eddy in relation to the Erastothenes Seamount and our sampling stations at the core and northern boundary core of the eddy, chlorophyll was present to $500 \mathrm{~m}$ depth, well below the water layer considered as the euphotic zone. At the time of sampling the mixing depth in the core, ca $350 \mathrm{~m}$ (Krom et al. 1993), was greater than the calculated critical depth $(<300 \mathrm{~m}$; Yentch \& Phinney 1985). According to classical theory, under such circumstances a phytoplankton bloom should not be initiated. Bishop et al. (1986) and Smetacek \& Passow (1990) have suggested that interim periods of quiescence during winter can temporarily prevent deep mixing thereby allowing phytoplankton populations to bloom even when theoretically the mixing depth is greater than the critical depth.

On the basis of conventional physical and chemical measurements made in the water column, it is only possible to determine the depth of winter mixing. No information can be obtained on the timing of that mixing nor on the rate of vertical mixing Phytoplankton populations are known to adjust their physiological responses to variations in the ambient light conditions (light-shade adaptation) and thus can potentially provide information about timing and rate of vertica] mixing. In particular, phytoplankton cells modify their cellular chlorophyll content depending on the light conditions at time scales of a few hours (Falkowski 1984): at low light intensities cellular chlorophyll content is increased, to increase the light-capturing capacity. This light-shade adaptation mechanism does not operate in complete darkness, e.g. at night. Flow cytometry allows the measurement of the chlorophyll fluorescence of individual cells, and thus provides a quick relative estimate of the chlorophyll content of phytoplankton.

In this study, we used these features of phytoplankton to put limits on the timing and rate of vertical mixing in the water column of the eddy. We also reexamined the critical depth concept and provide supportive field evidence to the Smetacek \& Passow (1990) modification to the theory.

\section{METHODS}

A cruise to the Cyprus Eddy was undertaken on 2 to 5 March 1992 aboard the RV 'Shikmona'. This cruise was conducted $4 \mathrm{~d}$ after a storm had passed through the region and within $24 \mathrm{~h}$ of an intrusion of cold air into the eastern end of the Levantine Basin. A series of stations was sampled for physical and chemical characteristics at $10 \mathrm{~km}$ intervals along N-S and E-W transects across the eddy. The center of the eddy was defined previously (Krom et al. 1992) as the site where the $15^{\circ} \mathrm{C}$ isotherm was deepest on both transects, and its boundary as the sites closest to the core where the deep mixing characteristics were no longer apparent. 
Water samples for chemical analyses (dissolved oxygen, nitrate, phosphate and silicate concentrations) were collected from a series of depths between the surface and $1400 \mathrm{~m}$. Details of sampling and analytical procedures for these chemical parameters are as in Krom et al. (1992).

After locating the eddy, additional biological samples were taken at core and northern boundary stations (Fig. 1). Water samples were collected from 18 depths within the upper $600 \mathrm{~m}$ with a General Oceanic rosette equipped with interchangeable sets of twelve 1.7 l or six 5 l Niskin bottles attached to a Neil-Brown conductivity, temperature, depth profiler (CTD). The boundary station $\left(34.08^{\circ} \mathrm{N}, 33.50^{\circ} \mathrm{E}\right)$ was sampled at $16: 00 \mathrm{~h}$ on 3 March; the core $\left(33.38^{\circ} \mathrm{N}, 33.50^{\circ} \mathrm{E}\right)$ at 06:00 h on 4 March. Samples for pigment concentrations, picoplankton, bacterial abundances and bacterial activity measurements were prefiltered through a $200 \mu \mathrm{m}$ mesh to eliminate macrozooplankton and large particles.

Subsamples $(250 \mathrm{ml})$ for chlorophyll determinations were filtered immediately after sampling onto GF/F filters. In addition, duplicate $500 \mathrm{ml}$ samples were collected; one replicate was filtered through a $2 \mu \mathrm{m}$ Nucleopore filter and another through a $10 \mu \mathrm{m}$ filter. The particulate matter remaining in the filtrates was collected on GF/F filters. The filters were wrapped in aluminum foil, stored at $-20^{\circ} \mathrm{C}$ and processed in the laboratory 1 wk later. Pigments were extracted in $90 \%$ acetone and chlorophyll $a, b$ and $c$ (chl $a, b$ and $c)$ were determined spectrofluorometrically according to Neveux et al. (1990).

A more detailed determination of pigment composition was carried out using reverse-phase high performance liquid chromatography (HPLC). Large volume (10 l) samples from 9 depths within the upper $500 \mathrm{~m}$ were filtered through GF/C filters, which were kept frozen in aluminum foil until analysis in the lab within 2 wk. The HPLC system consisted of a CM4000 (LDCMilton Roy) multiple solvent delivery pump, a Rheodyne injector and a $3 \mu \mathrm{m} \mathrm{C}-1833 \times 4.6 \mathrm{~mm}$ column (Perkin Elmer). The pigments were detected by a variable wavelength detector set at $436 \mathrm{~nm}$ and the chromatogram was recorded by a Cl-10B (LDC-Milton Roy) integrator. The experimental schedule of the HPLC system was a modification of those previously published by Klein \& Sournia (1987) and Zapata et al. (1987). Two solvents were used in the system: solvent A consisted of $30 \% 1 \mathrm{M}$ ammonium acetate (Sigma) in double-distilled deionized water, and $70 \%$ methanol (HPLC grade, Biolab); solvent B consisted of $30 \%$ ethylacetate (HPLC grade, Biolab) and $70 \%$ methanol The solvent program showed a linear increase of solvent $\mathrm{B}$ from 20 to $60 \%$ in $5 \mathrm{~min}$, then a linear increase from 60 to $100 \%$ solvent $B$ in $7 \mathrm{~min}$, followed by a hold at $100 \% \mathrm{~B}$ for 3 min. Peaks that showed on HPL chromatograms were identified on the basis of their retention time, compared to cultures of known pigment composition and purified pigments. Calibration curves for pigment quantification were made with purchased $c h l a$ and $b$ (Sigma), and from prepared chl $c$ and carotenoids, eluted on-line from the HPLC system. The isolated pigments were scanned at the range of 350 to $700 \mathrm{~nm}$ on a spectrophotometer (Kontron instrument), and their concentration determined using published extinction coefficients (Davis 1976).

Samples $(50 \mathrm{ml})$ for bacterial counts were preserved with a Lugol-Formaldehyde combination (Sherr et al. 1989) and counted using epifluorescence microscopy and 4:6-diamidino-2-phenylindole (DAPI) stain. Bacterial activity was measured using the ${ }^{3} \mathrm{H}$-methyl thymidine method as modified by Robarts \& Zohary (1993) for the ultraoligotrophic conditions of the Eastern Mediterranean. Samples for flow cytometry were collected in $1.5 \mathrm{ml}$ cryovials, preserved with $2.5 \%$ glutaraldehyde, and immediately frozen in liquid nitrogen. The frozen samples were kept at $-80^{\circ} \mathrm{C}$ until shipped to the Bedford Institute of Oceanography, Canada, where they were analyzed. Measurements of phytoplankton abundance and chlorophyll fluorescence per cell were performed as previously described (Li 1995). The identification of Prochlorococcus, Synechococcus, and eukaryotic ultraphytoplankton from cytometric signatures was based on interactive analysis of multiple bivariate scatterplots as described explicitly by Olson et al. (1993). Each sample was analyzed only once, but an indication of analytical confidence can be inferred from previous work ( $\mathrm{Li}$ 1990) which indicates an average coefficient of variation of $6 \%$ for the range of cytometric counts in the present work.

Secchi depth was measured with a white disk of $30 \mathrm{~cm}$ diameter. The depths to which 1 and $0.1 \%$ light penetrated were calculated from Secchi depth using equations developed for Eastern Mediterranean water and given in Megard \& Berman (1989).

\section{RESULTS}

\section{The physical-chemical environment}

During the period 23 to 26 February 1992, the eastern Levantine Basin was under the influence of a Cyprus low. During this storm, in the vicinity of the eddy the air temperature dropped to $9-10^{\circ} \mathrm{C}$ as compared to the normal value of 15 to $16^{\circ} \mathrm{C}$ for this time of year. The winds were westerly to northwesterly with speeds of 8 to $13 \mathrm{~m} \mathrm{~s}^{-1}$ By 27 February the storm had passed, daytime temperatures rose to $14^{\circ} \mathrm{C}$ and the 
wind speed dropped to $5 \mathrm{~m} \mathrm{~s}^{-1}$. Just prior to the cruise, on 1 to 2 March 1992 a localized ridge of high pressure developed to the west of Cyprus. As a result, winds in the vicinity of the eddy shifted to northerly, leading to an intrusion of cold air during which daytime temperatures dropped to $11^{\circ} \mathrm{C}$. During the cruise (2 to 5 March 1992) the weather was generally fair, winds shifted to westerly and temperatures gradually warmed to $17^{\circ} \mathrm{C}$. We note that the cold air intrusion prior to the cruise, even though during a period of fair weather, led to surface cooling that was nearly as intense as during the preceding storm.

At 06:00 h on March 4,1992, the water column at the core of the eddy was isothermal $\left(16.6^{\circ} \mathrm{C}\right)$ and isohaline (39.37 psu) to a depth of $500 \mathrm{~m}$ (Fig. 2). A deep pycnocline extended from 500 to $850 \mathrm{~m}$ beneath which Levantine Deep Water (LDW) was found, with a range of temperatures from 13.8 to $13.6^{\circ} \mathrm{C}$ and salinities from 38.85 to 38.78 psu, typical for LDW from this region (Hecht et al. 1988). Dissolved oxygen concentrations at the core were also uniform throughout the upper $500 \mathrm{~m}(222 \mu \mathrm{M})$, declined between 550 and $800 \mathrm{~m}$ and remained at a constant value of $172 \mu \mathrm{M}$ at deeper depths. Nutrient concentrations showed similar vertical distribution, with constant values from the surface to $500 \mathrm{~m}$ of $<0.01 \mu \mathrm{M}$ phosphate, $0.14 \mu \mathrm{M}$ nitrate, and 1.6 $\mu \mathrm{M}$ silicate. The nutricline coincided with the pycnocline and beneath it phosphate reached $0.22 \mu \mathrm{M}$ and nitrate exceeded $5 \mu \mathrm{M}$. Silicate concentration continued to increase slowly beneath the nutricline and exceeded $10 \mu \mathrm{M}$ at $1100 \mathrm{~m}$.
In contrast with the pattern of chemical distributions at the core, at the boundary station isothermal $\left(16.1^{\circ} \mathrm{C}\right)$ and isohaline (39.34) conditions extended only down to $150 \mathrm{~m}$ (Fig. 2). Slight warming together with a small decrease in salinity was observed at the surface. A more gradual pycnocline compared to that at the core extended from $150 \mathrm{~m}$ to $800 \mathrm{~m}$, beneath which typical LDW was found. Oxygen was also uniform throughout the upper $150 \mathrm{~m}$ (225 $\mathrm{MM}$ ), then declined with depth and reached the constant value of $172 \mu \mathrm{M}$ beneath $500 \mathrm{~m}$. Nutrient concentrations in the upper $150 \mathrm{~m}$ were $0.01 \mu \mathrm{M}$ for phosphate, $0.2 \mu \mathrm{M}$ for nitrate, and ranged from 1.8 to $2.0 \mu \mathrm{M}$ for silicate. Similar to the situation at the core, the nutricline coincided with the pycnocline and beneath it phosphate reached $0.22 \mu \mathrm{M}$ and nitrate exceeded $5 \mu \mathrm{M}$

The measured Secchi disk depths were $30 \mathrm{~m}$ at the core and $24.5 \mathrm{~m}$ at the boundary station. Megard \& Berman (1989) showed that in this region of the Eastern Mediterranean, 1\% light level is 3.04 times the Secchi disk depth (SDD) and the $0.1 \%$ light is at 4.56 times the SDD. Thus it was calculated that $1 \%$ of the light penetrated to $91 \mathrm{~m}$ at the core and to $75 \mathrm{~m}$ at the boundary and $0.1 \%$ to 137 and $112 \mathrm{~m}$ respectively. The typical midday incident light in this region in early March is ca $1000 \mu$ Einst $\mathrm{m}^{-2} \mathrm{~s}^{-1}$.

\section{Spectrofluorometrically determined chlorophylls}

The depth profiles of chl a mirrored approximately those of nutrients (Figs. $2 \& 3$ ). At the core of the eddy,
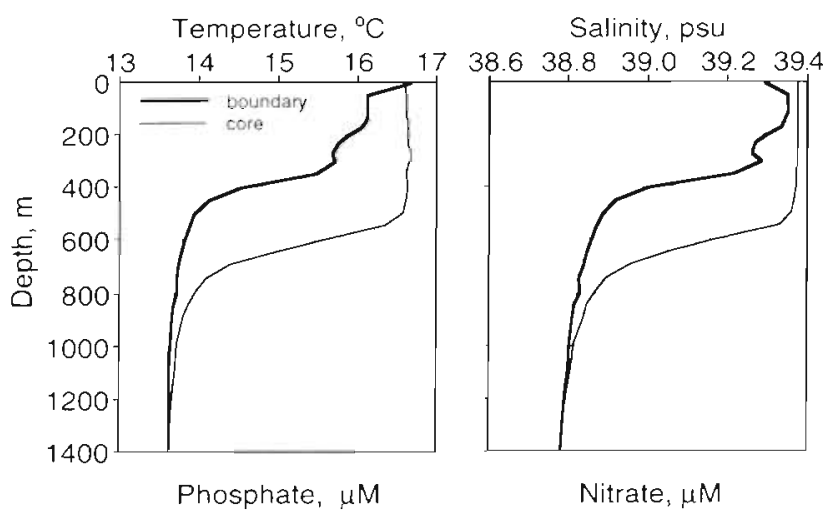

Nitrate, $\mu \mathrm{M}$
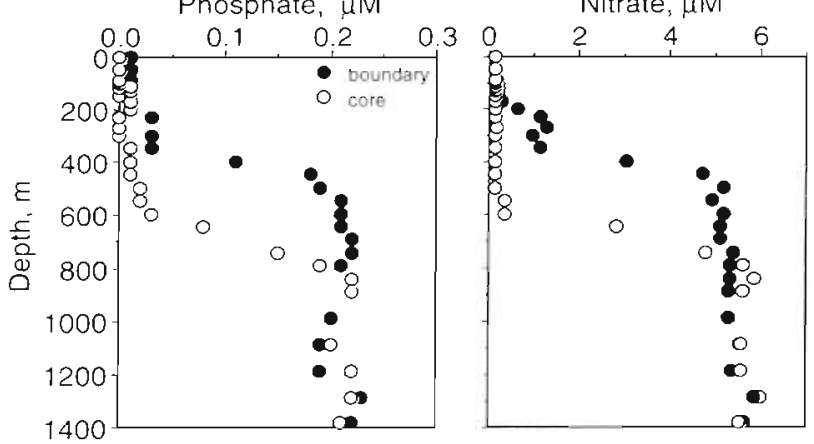
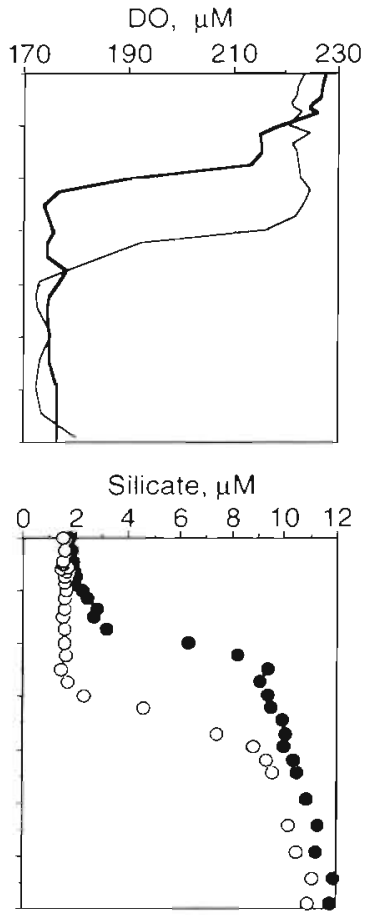

Fig. 2. Depth profiles of temperature, salinity, dissolved oxygen (DO) and nutrient concentrations at the northern boundary and core of the Cyprus Eddy, March 1992. Boundary was sampled at 16:00 h on 3 March; core at 06:00 h on 4 March 
Core Concentration, ng I-1 $^{-1}$
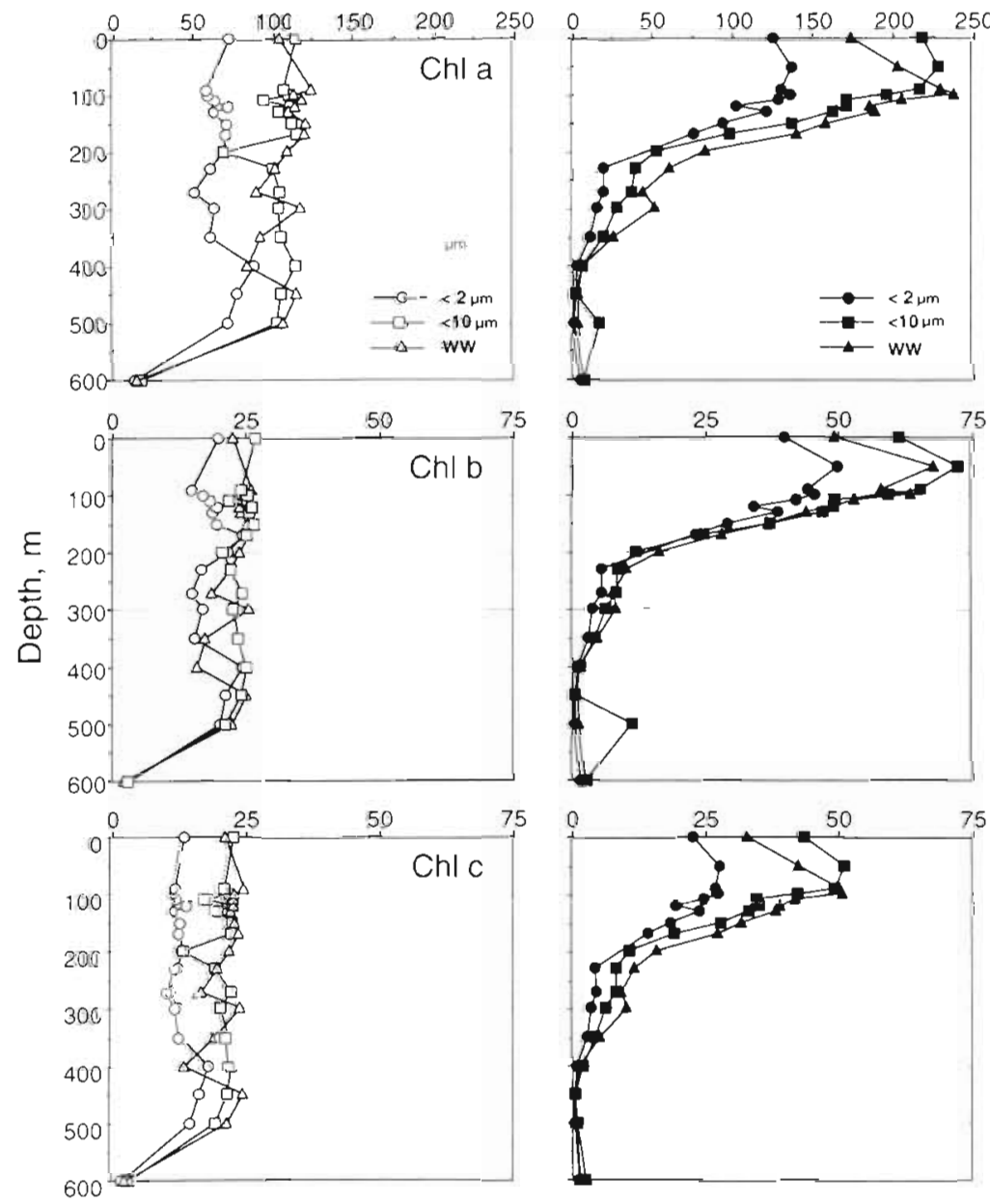

Fig. 3. Depth profiles of spectrofluorometrically determined concentrations of chlorophyll (chl) $a, b$, and $c$ in whole (WW) and size-fractionated $k 2 \mu \mathrm{m}$, $<10 \mu \mathrm{m}$ ) seawater at the core and northern boundary of the Cyprus Eddy, 3-4 March 1992

spectrofluorometrically determined concentrations of chl a were more or less evenly distributed from the surface to $500 \mathrm{~m}$ depth (range: 85 to $123 \mathrm{ng} \mathrm{l}^{-1}$ ), with an average concentration of $110 \mathrm{ng}^{-1}$. On average, $98 \%$ of the chl $a$ was found in particles $<10 \mu \mathrm{m}$ and $64 \%$ in particles $<2 \mu \mathrm{m}$ (Fig. 3, Table 1). The depth distributions of $c h l b$ and $c$ were similar although at considerably lower concentrations (16 to $26 \mathrm{ng} \mathrm{chl} b \mathrm{l}^{-1} ; 14$ to $25 \mathrm{ng} \mathrm{chl} c \mathrm{l}^{-1}$ ). A distinctly greater proportion of chl $b$ (compared to chl a) was found in particles smaller than $2 \mu \mathrm{m}$ (Table 1 ).

At the boundary station pigments were depth-distributed as expected in Eastern Mediterranean oceanic waters (Fig. 3). At $110 \mathrm{~m}$, chl a concentration reached a peak of $230 \mathrm{ng} \mathrm{l}^{-1}$, which was double the highest concentration at the core, but then declined sharply with depth between 110 and $280 \mathrm{~m}$ depth. Depth integration over the entire upper $500 \mathrm{~m}$ column showed that the chlorophyll content was about $30 \%$ greater at the core than that at the boundary (Table 1). For all 3 chlorophylls, the fractions contained in small particle sizes were somewhat larger in the core than in the boundary (Fig. 3, Table 1).

\section{HPLC-determined pigment composition}

Chlorophylls $a, b$ and $c$, the carotenoids $19^{\prime}$ butanoyloxy fucoxanthin (BF), fucoxanthin, 19' hexanoyloxy fucoxanthin $(\mathrm{HF})$, zeaxanthin and carotene were the prominent photosynthetic pigments in our samples and were present in all HPLC chromatograms. In the core, the distribution of total accessory pigments as well as that of the individual pigments, including fucoxanthin, chl $b$ and HF, were more or less uniform with depth (Fig. 4). In contrast, at the boundary the total amount dropped dramatically between 130 and $200 \mathrm{~m}$. Furthermore, in the core, at all depths the total amount of accessory pigments exceeded $60 \%$ of the amount of chl a whereas at the boundary the proportion was generally lower. The relative concentration of $c h l b$, particularly within the euphotic zone, was on average higher at the core than at the boundary.

Table 1. Depth-integrated ( 0 to $500 \mathrm{~m}$ ) chlorophyll content $\left(\mathrm{mg} \mathrm{m}^{-2}\right.$ ) in unfiltered seawater (Total) and in the $<10 \mu \mathrm{m}$ and $<2 \mu \mathrm{m}$ fractions. Data are also expressed as \% of the amount in the unfiltered water

\begin{tabular}{|c|c|c|c|c|c|c|c|c|c|}
\hline \multirow[t]{2}{*}{ Station } & \multicolumn{3}{|c|}{ Chlorophyll a } & \multicolumn{3}{|c|}{ Chlorophyll b } & \multicolumn{3}{|c|}{ Chlorophyll $c$} \\
\hline & Total & $<10 \mu \mathrm{m}$ & $<2 \mu \mathrm{m}$ & Total & $<10 \mu \mathrm{m}$ & $<2 \mu \mathrm{m}$ & Total & $<10 \mu \mathrm{m}$ & $<2 \mu \mathrm{m}$ \\
\hline Core & $\begin{array}{c}59.0 \\
(100 \%)\end{array}$ & $\begin{array}{c}58.0 \\
(98 \%)\end{array}$ & $\begin{array}{c}37.9 \\
(64 \%)\end{array}$ & $\begin{array}{c}12.4 \\
(100 \%)\end{array}$ & $\begin{array}{c}13.2 \\
(>100 \%)\end{array}$ & $\begin{array}{c}10.6 \\
(85 \%)\end{array}$ & $\begin{array}{c}11.7 \\
(100 \%)\end{array}$ & $\begin{array}{c}11.5 \\
(98 \%)\end{array}$ & $\begin{array}{c}7.5 \\
(64 \%)\end{array}$ \\
\hline Boundary & $\begin{array}{c}45.5 \\
(100 \%)\end{array}$ & $\begin{array}{c}42.3 \\
(93 \%)\end{array}$ & $\begin{array}{c}24.7 \\
(53 \%)\end{array}$ & $\begin{array}{c}11.5 \\
(100 \%)\end{array}$ & $\begin{array}{c}12.5 \\
(>100 \%)\end{array}$ & $\begin{array}{c}8.1 \\
(71 \%)\end{array}$ & $\begin{array}{c}9.3 \\
(100 \%)\end{array}$ & $\begin{array}{c}8.9 \\
(96 \%)\end{array}$ & $\begin{array}{c}5.0 \\
(54 \%)\end{array}$ \\
\hline
\end{tabular}




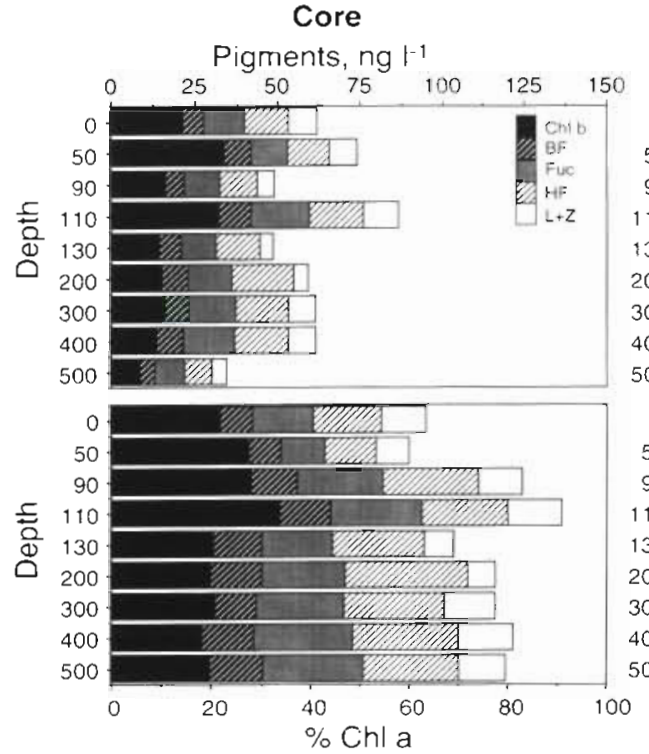

The suite of HPLC determined pigments suggest that the phytoplankton population was dominated by prymnesiophytes (chl $c+$ fucoxanthin $+\mathrm{HF}$ or $\mathrm{BF}$ ), prochlorophytes (zeaxanthin + chl b), and cyanobacteria (zeaxanthin) (Rowan 1989). Although fucoxanthin is the major carotenoid of the diatoms, the small quantities of another major carotenoid of diatoms, diadinoxanthin (Stauber \& Jeffrey 1988), suggests low presence of this taxonomic group in our samples, as was also suggested by the relatively low fraction of the total chlorophyll contained in the $>10 \mu \mathrm{m}$ fraction (Fig. 3). The abundance of chl $b$, particularly in the $<2 \mu \mathrm{m}$ fraction, suggests high abundance of prochlorophytes, although due to their minute size their contribution to total phytoplankton chl a was estimated to be only 10 to $15 \%$ (see below). Chl $b$ is present also in other algal groups (chlorophytes, prasinophytes), but we did not detect the auxiliary carotenoids associated with these other taxa.

\section{Ultraplankton abundance}

Flow cytometric analysis has shown that the ultraand pico-phytoplankton populations consisted of 3 main groups: eukaryotic cells, cyanobacteria (Synechococcus) and prochlorophytes (Prochlorococcus). The distinct differences between the core and boundary stations was also apparent in the vertical distribution of these phytoplankton groups (Fig. 5). At the core station, eukaryotic cells, Synechococcus and Prochlorococcus were evenly distributed with depth down to $500 \mathrm{~m}$. Eukaryotes numbered ca 1000 cell $\mathrm{ml}^{-1}$, cyanobacteria about $1200 \mathrm{ml}^{-1}$ and prochlorophytes
Boundary

Pigments, ${ }_{50} \ln _{100} \mathrm{I}^{-1}$

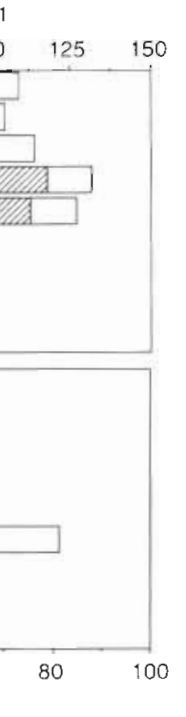

Fig. 4. Depth profiles of HPLCdetermined indicator pigments expressed as concentrations (upper panel) and as proportion of chl a (lower panel) at the core and boundary of the Cyprus Eddy, 3-4 March 1992. Chl $b$ : chlorophyll $b$; BF: 19' butanoyloxy fucoxanthin; Fuc: fucoxanthin; HF: 19' hexanoyloxy fucoxanthin, L+Z: lutein + zeaxanthin

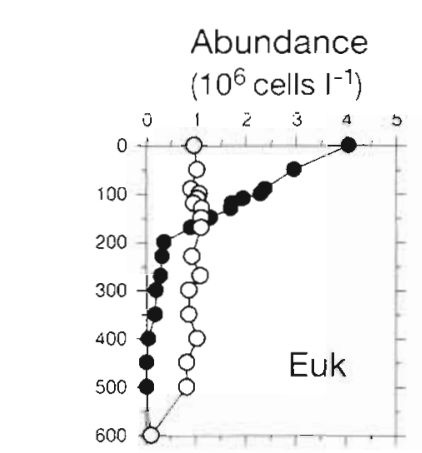

\section{Fluorescence per cell} (arbitrary units)
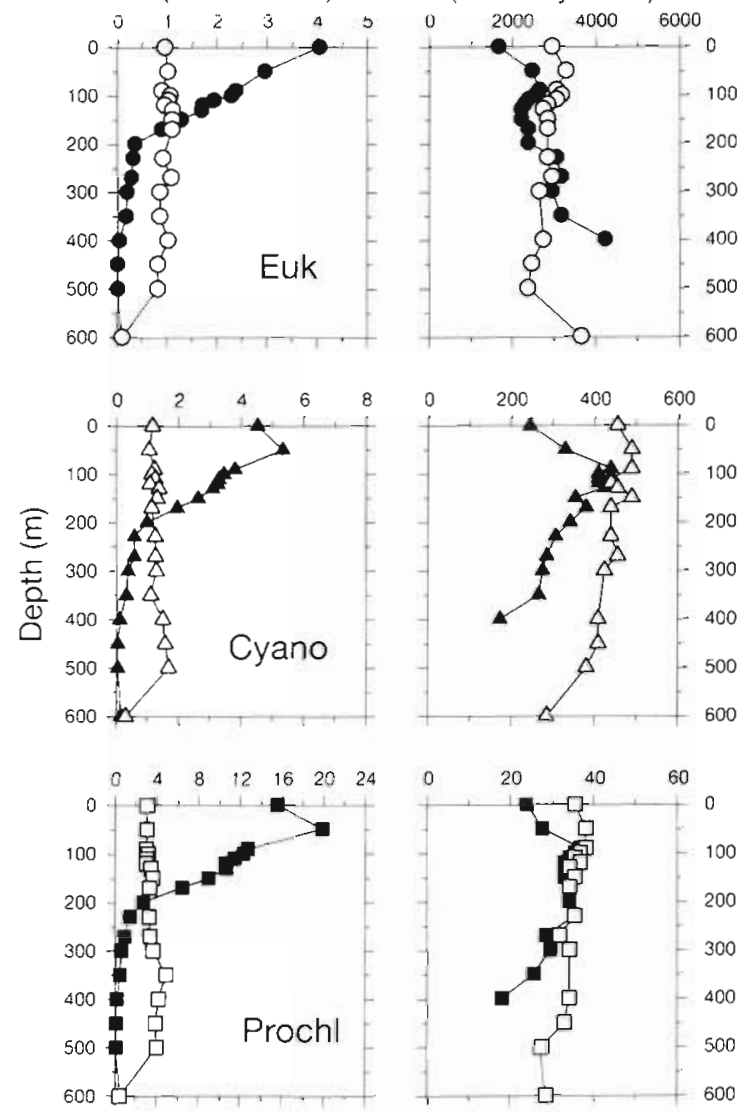

Fig. 5. Depth distribution of ultraplankton analyzed by flow cytometry at the core $(0, \Delta, \square)$ and boundary $(\bullet, \Delta, \mathbf{v})$ of the Cyprus Eddy, March 1992, showing properties for eukaryotic ultraplankton (Euk, top panels), cyanobacteria (Cyano, middle panels) and prochlorophytes (Prochl, bottom panels). Left column shows cell abundances; right column shows chlorophyll fluorescence per cell 
about $3000 \mathrm{ml}^{-1}$. At the boundary peak abundances were recorded at the surface (for eukaryotes) or at $50 \mathrm{~m}$ (for Synechococcus and Prochlorococcus), while most organisms disappeared by $200 \mathrm{~m}$. At the core, neither cell abundance nor mean chlorophyll fluorescence per cell varied with depth, whereas at the boundary station distinct depth-dependent patterns were evident for fluorescence per cell of the 3 groups (Fig. 5).

Total chlorophyll can be partitioned amongst the 3 phytoplankton groups if the ratio of chlorophyll to fluorescence is known for each group (Li et al. 1993). These ratios are not known for the conditions under study. However, as a first approximation, we made this partition using the relevant ratios derived previously by multiple regression ( $\mathrm{Li}$ et al. 1993) for the station closest to the present ones. Over the depth integral 0 to $500 \mathrm{~m}$, total chlorophyll calculated from cytometric measurements (Table 2) equaled the direct spectrofluorometric determination (Table 1) at the core, but overestimated that at the boundary. The partition of calculated chlorophyll was 10 to $15 \%$ Prochlorococcus, 32 to $34 \%$ Synechococcus, and 51 to $58 \%$ eukaryotic phytoplankton (Table 2).

\section{Bacterial abundance and activity}

As with all the other parameters, bacterial numbers and production were evenly distributed throughout the upper $500 \mathrm{~m}$ at the core of the eddy, but not at the boundary (Fig. 6). At the core, bacteria numbered between 2.5 and $3.5 \times 10^{5}$ cells $\mathrm{ml}^{-1}$ at all depths. Bacterial rates of thymidine incorporation were extremely low, close to the detection level of the method, mostly

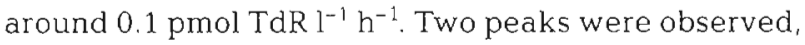
one at about 100 to $130 \mathrm{~m}$ and a second at 280 to $300 \mathrm{~m}$ depth. Both of these peaks coincided with small peaks

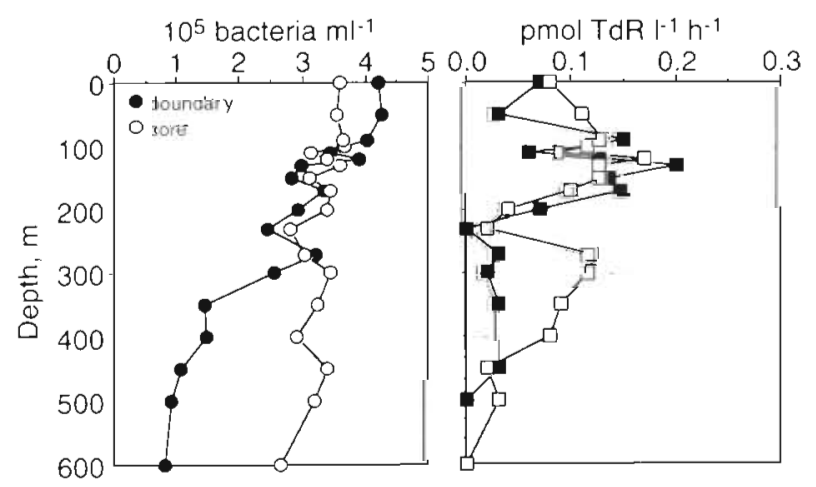

Fig. 6. Bacterial numbers and bacterial activity (expressed as rates of thymidine incorporation into DNA; pmol $\mathrm{TdR} \mathrm{l}^{-1} \mathrm{~h}^{-1}$ ) at the core and boundary of the Cyprus Eddy, 3-4 March 1992
Table 2. Depth-integrated (0 to $500 \mathrm{~m}$ ) chlorophyll $\left(\mathrm{mg} \mathrm{m} \mathrm{m}^{-2}\right.$ ) calculated from flow cytometric measurements indicating partition amongst Synechococcus (CYA), Prochlorococcus (PRO), and eukaryotic ultraphytoplankton (EUK). Values in parentheses are percentages of the sum

\begin{tabular}{|lcccc|}
\hline Station & CYA & PRO & EUK & Sum \\
\hline Core & 18.9 & 6.2 & 34.7 & 59.8 \\
& $(32 \%)$ & $(10 \%)$ & $(58 \%)$ & \\
Boundary & 18.9 & 8.1 & 28.6 & 55.7 \\
& $(34 \%)$ & $(15 \%)$ & $(51 \%)$ & \\
& & & & \\
\hline
\end{tabular}

in bacterial numbers. At the boundary, there was a gradual decline in bacterial numbers with depth, from $>4 \times 10^{5}$ cells $\mathrm{ml}^{-1}$ at the surface to $2.6 \times 10^{5}$ cells $\mathrm{ml}^{-1}$ at $300 \mathrm{~m}$ and then a sharper decline to $1.2 \times 10^{5}$ cells $\mathrm{ml}^{-1}$ at $350 \mathrm{~m}$ followed by a slow decline down to $500 \mathrm{~m}$. The bulk of bacterial production occurred within the upper $200 \mathrm{~m}$ (Fig. 6)

\section{DISCUSSION}

\section{A winter bloom in the Cyprus Eddy}

The eruption of Mount Pinatubo in the Philippines led to a cold air-temperature anomaly throughout the Middle East during the winter of 1992, associated with more stormy weather and higher precipitation than the multiannual means (Robock \& Mao 1992). As explained later, this anomaly was the cause for the deeper winter mixing in the Cyprus Eddy (>500 m) than the typical 350 to $400 \mathrm{~m}$ reported by Brenner et al. (1991). Exceptionally deep vertical mixing (>850 m) was reported that winter also in the Gulf of Aqaba (Genin et al. 1996)

The eddy sampled in this study had many of the chemical and physical features of the eddy studied in detail in 1988/89 by Krom et al. (1991, 1992, 1993). In particular, there was also a deep mixed layer in the core of the eddy which was depleted in phosphate but not in nitrate or silicate. However, the eddy sampled in this study was actually not the same body of water as the one examined previously by Krom et al. (1991, 1992, 1993). Brenner $(1993,1996)$ showed that, based on temperature/salinity properties sampled over a period of $5 \mathrm{yr}$, the water in the core is renewed every 2 to $3 \mathrm{yr}$.

The seasonal cycle in the Mediterranean Sea is characterized by a peak in productivity following deep winter mixing, which diminishes after the onset of summer stratification, when primary production depends on regenerated nutrients (Thingstad \& Rassoulzadegan 1995). In previous studies (Li et al. 1993, Yacobi et al. 1995, Robarts et al. 1996) we examined 
the spatial distribution of various biological parameters throughout the southern Levantine basin in autumn, i.e. towards the end of the annual production cycle. These studies demonstrated an ultra-oligotrophic situation, with a distinct lateral homogeneity in the depth distribution of nutrients, phytoplankton and bacteria in the upper $200 \mathrm{~m}$, with a characteristic deep chlorophyll maximum (DCM) at 90 to $100 \mathrm{~m}$ depth. The only exception noticed was at the core of the warm-core Ierapetra Eddy southeast of Crete, where the depthdistribution was uniform, with no DCM.

The Cyprus Eddy was not sampled in these previous studies. However, when comparing the data from those studies with autumn data from Krom et al. (1992) it is apparent that the vertical distributions of nutrients and chlorophyll at the Cyprus Eddy boundaries were similar to those reported from the rest of the eastern Mediterranean but that the core was different. Based on those observations, we assume that the same holds true in winter and that in this study the boundary station represented the situation in winter throughout most of the southern Levantine Basin, whereas the core station represented a pattern characteristic of a warm-core eddy. As far as we know, this is the first detailed description of the microbial populations in a warm-core eddy during the bloom season.

The differences between the eddy core and its surrounding sea resulted from the different mixing patterns. In the core, all the biological parameters examined were evenly distributed with depth over the $500 \mathrm{~m}$ upper layer, including photosynthetic and accessory pigments, abundance and cellular chlorophyll content of 3 ultraphytoplankton taxa, bacterial abundance and bacterial activity, whereas in the surrounding sea a distinct stratification was apparent, with organism abundance and activities diminishing beneath 150 to $200 \mathrm{~m}$ depth. Secchi transparency was greater in the core, probably due to the lower pigment concentrations in the uppermost $100 \mathrm{~m}$ (although the depth-integrated value was greater in the core). Based on the FC and HPLC analyses, it seemed that the same phytoplankton taxa occurred both within and outside the eddy, although the relative abundance of the different components was different.

Krom et al. (1992) found that in 1989 deep winter mixing was initiated in late January/early February and continued until late March. When they sampled the eddy core in mid-February, there was already a phytoplankton bloom, based on the highest depthintegrated chlorophyll value over the year $\left(70 \mathrm{mg} \mathrm{m}^{-2}\right)$, which was also considerably higher than the value at their boundary station $\left(44 \mathrm{mg} \mathrm{m}^{-2}\right)$. In the present study a similar phytoplankton bloom was found in the core of the eddy in early March, with a higher depth- integrated chl a content ( $59 \mathrm{mg} \mathrm{m}^{-2}$ ) than at the boundary station ( $45 \mathrm{mg} \mathrm{m}^{-2}$ ) and a considerably higher chl a content than at the core in October $1990\left(13 \mathrm{mg} \mathrm{m}^{-2}\right.$; Zohary et al. unpubl.) or in November $1989\left(10 \mathrm{mg} \mathrm{m}^{-2}\right.$; Krom et al. 1992). This pattern has been found previously for other warm-core eddies (Tranter et al. 1980, Bradford et al. 1982, Jeffrey \& Hallegraeff 1987) and rings (Nelson et al. 1985).

The deep mixing probably enhanced productivity via several interacting mechanisms, the obvious one being increased nutrient availability. Another likely mechanism that may have contributed to the development of the bloom is reduced grazing pressure due to the dilution of grazers. Not only does the portion of the mixed community subjected to sufficient light grow faster because of the added nutrients, their removal rate also decreases because the grazers have been diluted.

A principal difference, however, between the enhanced productivity in the Cyprus Eddy and that observed previously in other eddies or rings is that the bloom in the Cyprus Eddy occurred in mid-winter, simultaneously with the deep winter mixing, and was not delayed until the establishment of stratification. In the rings observed off Australia and in the Gulf Stream, phytoplankton blooms were not initiated until thermal stratification had occurred and deep mixing ceased. In fact, the evidence suggests that the Cyprus Eddy bloom may have already peaked some time before our early March sampling, since the depthintegrated chl a was lower than that found in midFebruary 1989, and also because the amount of nitrate left in the water column (0.2 $\mu \mathrm{M})$ was less in March 1992 compared to the amount in mid-February 1989 $(0.6 \mu \mathrm{M})$.

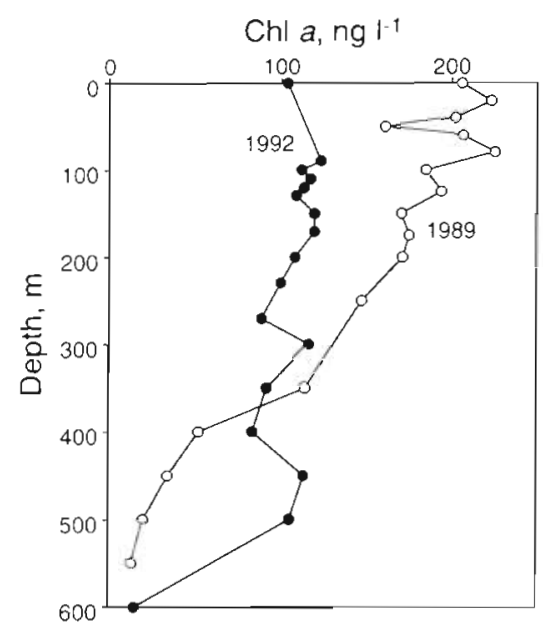

Fig. 7. Depth-distributions of chl a in the core of the Cyprus Eddy in winter. (O) 17 February 1989 (data from Krom et al. 1992); (•) 4 March 1992 (this study) 
The timing of a phytoplankton bloom in the presence of excess nutrients is generally considered to occur when phytoplankton receive sufficient light to sustain photosynthesis. This is a function of both light penetration and mixing depth (Sverdrup 1953, Smetacek \& Passow 1990). The critical depth for the Cyprus Eddy in March 1992, calculated as in Yentsch \& Phinney (1985), was approximately $300 \mathrm{~m}$. This is expected to be a maximum estimate by analogy with the calculation for the warm core ring WCR $82 \mathrm{~B}$ (Bishop et al. 1986). Nevertheless, in this study we observed viable, evenly distributed phytoplankton and bacteria to a depth of $500 \mathrm{~m}$.

The shape of the chlorophyll curve at the core of the Cyprus Eddy in winter 1992 was different from that reported by Krom et al. (1992) from winter 1989 (Fig. 7). In 1989, chl a was more or less evenly distributed with depth over the upper ca $150 \mathrm{~m}$, then declined at an approximately linear rate down to $400 \mathrm{~m}$, and then declined at a faster rate to near-zero at a depth of $550 \mathrm{~m}$. In winter 1992, chl a (as well as other pigments, phytoplankton and bacterial cell abundances and bacterial activity) were evenly distributed over the entire upper $500 \mathrm{~m}$. A possible explanation to the different depth distributions of chl a within the core is different vertical mixing conditions. The 1989 sampling followed a short-term quiescent period caused by low wind and/or temporary heat gain from the atmosphere, which reduced the rate of vertical mixing. Prior to and during the 1989 cruise, the weather was fair, daytime temperatures were 16 to $17^{\circ} \mathrm{C}$, and winds were light with speeds of 3 to $8 \mathrm{~m} \mathrm{~s}^{-1}$. Such conditions would enhance phytoplankton growth, especially within the upper part of the euphotic zone, by maintaining them in a favorable light environment, whereas the deeper layers remain in the dark. The storm and cold air intrusion that preceded our March 1992 sampling caused the complete mixing of the $500 \mathrm{~m}$ water column, leading to the observed homogeneous depth distribution.

\section{Vertical mixing rates}

The deep mixing and the uniform profiles of the physical, chemical, and biological parameters at the core are dependent upon a combination of several factors: the pre-existing subsurface profiles of temperature and salinity; the intensity of the surface cooling; and the time of sampling relative to the diel cycle. The typical winter mixed layer in this region reaches a depth of 150 to $200 \mathrm{~m}$ as seen at the boundary. This defines the depth of the seasonal thermocline. An unusually cold winter such as 1991/92 will force the typical mixed layer to be somewhat deeper but cer- tainly not by several hundred meters. The establishment of the deep mixed layer at the core depends on the typical winter mixing combined with the presence of a subsurface isothermal layer, or thermostad, at the base of the seasonal thermocline. This thermostad is essentially the remnant of the eddy signal from the previous winter (Brenner et al. 1991, Brenner 1993). Once the seasonal thermocline has eroded, the surface mixed layer combines with the thermostad to form a single deep mixed layer. The timing of this joining of the 2 layers depends upon the intensity of the atmospheric forcing. During the extremely cold winter of $1991 / 92$ it most likely occurred earlier than usual, perhaps as early as the beginning or middle of January. The water column at the core was therefore exposed to intense surface cooling for longer than normal, which explains the unusually deep mixing. Once the water column is well mixed, the density lapse rate is neutral so that it becomes easier to continue to mix the layer. With the same surface cooling it is therefore possible to maintain the deep convection at the core while at the boundary the mixing is constrained by the underlying thermocline at $200 \mathrm{~m}$.

In addition to being transported vertically by the physical mixing, the microbial populations in the euphotic zone arc affected by the diel cycle. At both the core and the boundary, the euphotic zone, defined as the layer overlying the depth to which $1 \%$ of incident light penetrates, is much shallower than the mixed layer. The even distribution with depth of chlorophyll fluorescence per cell (fluo/cell) for all 3 ultraplankton groups at the core (Fig. 5) suggests that the cells did not have time to make physiological adjustments to the light environment at their specific depth. Since these cells were sampled approximately at sunrise, their last opportunity to change their pigment composition in response to changes in the light climate would have been during the light hours of the previous day.

In contrast, at the boundary the depth distribution of fluo/cell was indicative of light-shade adaptation. Cyanobacteria had a distinct peak of fluo/cell around $100 \mathrm{~m}$, prochlorophytes between 100 and $250 \mathrm{~m}$. For eukaryotes the pattern was less distinct, but still, fluo/cell increased with depth over the upper $100 \mathrm{~m}$ where the light gradient was largest, suggesting lightshade adaptation took place. Had the water column at the boundary station been recently mixed, we would have expected the fluo/cell to be uniform over the upper $150 \mathrm{~m}$. It follows that in the core vertical mixing occurred recently, possibly as convective mixing during the night of 3-4 March. Thus, we suggest that, had we sampled the core in the late afternoon hours of 3 March instead of early in the next morning, we probably would have observed the fluo/cell profile typical of light-shade adaptation 
This enabled us to put an upper limit to the last time the upper $500 \mathrm{~m}$ at the core station mixed. Assuming that light-shade adaptation changes do not take place at night, and in light of the fact that our sampling was at sunrise, it is possible that the water column was actively mixing at the time of sampling or that it had been actively mixing until same point in any time during the previous night. But not much before that: had the last mixing event taken place during the previous day, followed by several hours of daylight, we would have expected to see a characteristic light-shade adaptation profile at the core. Therefore, we concluded that the last deep vertical mixing event could have still been going on, but must have taken place at the latest ca 12 to $15 \mathrm{~h}$ before sampling. With a $500 \mathrm{~m}$ water column, we calculate a lower limit for vertical mixing rates in the order of $500 / 15=33 \mathrm{~m} \mathrm{~h}^{-1}$. This conservative estimate falls close to the upper limit of the wide range of 0.14 to $40 \mathrm{~m} \mathrm{~h}^{-1}$ suggested by Falkowski (1983), suggesting that vertical mixing rates were high.

In contrast, in February 1989 sampling was carried out during a period of calm weather. Furthermore, the core station was then sampled between 23:00 and 01:00 h. While we do not have fluo/cell data for this cruise, the depth distribution of chl a suggests that the upper $500 \mathrm{~m}$ of the water column had not been mixed for at least several days, causing the depletion with depth of chl a (Fig. 7). Thus, the 1992 profile is representative of a time of active deep vertical mixing, whereas the 1989 profile is representative of an interim period of quiescence between mixing events that allows cells in the euphotic zone to take advantage of the new nutrients and photosynthesize. Jointly, those 2 types of processes allow phytoplankton blooms in the Eastern Mediterranean to develop even during winter.

In summary, our study has shown that in the Eastern Mediterranean, phytoplankton blooms develop concomitantly with winter deep mixing and are more pronounced within a warm-core eddy, where mixing is even deeper and more intense than in the oceanic water outside the eddy boundaries. Vertical mixing can. be vigorous, at least $30 \mathrm{~m} \mathrm{~h}^{-1}$. Our data suggest some modification to the critical depth concept: blooms can develop when mixing is deeper than the critical depth, providing that mixing is intermittent, with interim quiescence periods when active growth takes place.

Light-shade adaptation characteristics of the phytoplankton can be used to conveniently put an upper limit to vertical mixing rates, when supporting physical data are unavailable. In order to minimize the uncertainties about the estimates, measurements of fluo/cell or cellular chlorophyll content should be taken several times during the diel cycle, especially during daylight hours.
Acknowledgements. This project was supported by a grant 92-06-024 from the Israel Ministry of Energy and Infrastructure. We thank the crew of the RV 'Shikmona' and Nir Koren for help at sea. Sara Chava counted the bacteria; Lora Izrailoy carried out the nutrient analyses, Nurit Gordon the chlorophyll determinations; Ester Lubzantz provided equipment and help with cryo-preservations, and Dave Hambright prepared the map. We thank Paul Falkowski and Victor Smetacek for useful comments on early drafts.

\section{LITERATURE CITED}

Bishop JKB, Conte $\mathrm{MH}$, Wiebe $\mathrm{PH}$, Roman MR, Langoon C (1986) Particulate matter production and consumption in deep mixed layers: observations in a warm core ring. Deep Sea Res 33:1813-1841

Bradford MR, Heath RA, Chang FH, Hay CH (1982) The effect of warm-core eddies on oceanic productivity off northeastern New Zealand. Deep Sea Res 29:1501-1516

Brenner S (1989) Structure and evolution of warm core eddies in the Eastern Mediterrancan Levantine Basin. J Geophys Res 94:12593-12602

Brenner S (1993) Long term evolution and dynamics of a persistent warm core eddy in the Eastern Mediterranean Sea. Deep Sea Res il 40:1193-1206

Brenner S (1995) The relationship betwocn atmospheric forcing and the Shikmona Gyre. International POEMBC/MTP Symposium, Molitg Les Bains, France, 1-2 July 1996, p $87-89$

Brenner S (1997) Long term climatological simulations of the general circulation in the Levantine Basin. In: Galil B, Mart Y (eds) Procedings of the Ninth Symposium on the Mediterranean Continental Margin of Israel, Haifa, June 1997, p 26-30 (available from IOLR)

Brenner S, Rosentraub Z, Bishop J, Krom M (1991) The mixed layer/thermocline cycle of a persistent warm core eddy in the eastern Mediterranean. Dyn Atmos Oceans 15:457-476

Davis BH (1976) Carotenoids. In: Goodwin TW (ed) Chemistry and biochemistry of plant pigments, Vol 2. Academic Press, London, p 38-165

Falkowski PG (1983) Light-shade adaptation and vertical mixing of marine phytoplankton: a comparative field study. J Mar Res 41:215-237

Falkowski PG (1984) Physiological responses of phytoplankton to natural light regimes. J Plankton Res 6:295-307

Genin A, Lazar B, Brenner S (1996) Vertical mixing and coral death in the Red Sea following the eruption of Mount Pinatubo. Nature 377:507-510

Hecht A, Pinardi N, Robinson AR (1988) Currents, water masses, eddies, and jets in the Mediterranean Levantine Basin. J Phys Oceanogr 18:1320-1353

Jeffery JW, Hallegraeff GM (1987) Phytoplankton pigments, species and light climate in a complex warm-core eddy of the East Australian Current. Deep Sea Res 34:649-673

Jenkins WJ (1988) Nitrate flux into the euphotic zone near. Bermuda. Nature 331:521-523

KIein B. Sournia A (1987) A daily study of the diatom spring bloom at Roscoff (France) in 1985. II. Phytoplankton pigment composition studied by HPLC analysis. Mar Ecol Prog Ser 37:265-275

Krom MD, Brenner S, Kress N, Neori A, Gordon LI (1992) Nutrient dynamics and new production in a warm-core eddy from the E Mediterranean Sea. Deep Sea Res 39: $467-480$

Krom MD, Brenner S, Kress N, Neori A, Gordon Ll (1993) Nutrient distributions during an annual cycle across a 
warm-core eddy from the E Mediterranean Sea. Deep Sea Res I 40:805-825

Krom MD, Kress N, Brenner S, Gordon LI (1991) Phosphorus limitation of primary productivity in the Eastern Mediterranean. Limnol Oceanogr 36:424-432

Li WKW (1990) Particles in 'particle-free' seawater: growth of ultraphytoplankton and implications for dilution expenments. Can J Fish Aquat Sci 47:1258-1268

Li WKW (1995) Composition of ultraphytoplankton in the central North Atlantic. Mar Ecol Prog Ser 122:1-8

Li WKW, Dickie PM, Irwin BD. Wood AM (1992) Biomass of bacteria, cyanobacteria, prochlorophytes and photosynthetic eukaryotes in the Sargasso Sea. Deep Sea Res 39 501-519

Li WKW, Zohary T, Yacobi YZ, Wood AM (1993) Ultraphytoplankton in the eastern Mediterranean Sea: towards deriving phytoplankton biomass from flow cytometric measurements of abundance, fluorescence and light scatter. Mar Ecol Prog Ser 102:79-97

Malanotte-Rizzoli P, Robinson AR, Roether W, Manca B, Bergamasco A, Brenner S, Civitarese G, Georgopoulos D, Haley PJ, Kioroglou S, Kontoyannis H, Kress N, Latif MA, Leslie WG, Ozsoy E, Riberad 'Alcala' M, Salihoglu I, Sansone $E$ and Theocharis A (1996) Experiment in Eastern Mediterranean probes origin of deep water masses. EOS $77(32)$

Megard RO, Berman T (1989) Effects of algae on the Secchi transparency of the southeastern Mediterranean Sea. Limnol Oceanogr 34:1640-1655

Nelson DM, Ducklow HW, Hitchcock GL, Brzezinski MA, Cowles TJ, Garside C, Gould RW, Joyce TM, Langdon C, McCarthy JJ, Yentch CS (1985) Distribution and composition of biogenic particulate matter in a Gulf Stream warmcore ring. Deep Sea Res 32:1347-1369

Neveux J, Delmas D, Romano JC, Algarra P, Ignitiades L, Herbland A, Morand P, Neori A, Bonin D, Barbe J, Sukenik A, Berman T (1990) Comparison of chlorophylls and phaeopigments determinations by spectrophotometric, fluorometric, spectrofluorometric and HPLC methods. Mar Microb Food Webs 4:217-238

Olson RJ, Zettler ER, DuRand MD (1993) Phytoplankton analysis using flow cytometry. In: Kemp PF, Sherr BF, Sherr EB, Cole JJ (eds) Handbook of methods in aquatic microbial ecology. Lewis Publishers, Boca Raton, p 175-186

Robarts RD, Zohary T (1993) Fact or fiction - bacterial growth and production as determined by $\left[{ }^{3} \mathrm{H}\right.$-methyl $]$ thymidine. Adv Microb Ecol 13:371-425

Editorial responsibility: John Dolan (Contributing Editor). Villefranche-Sur-Mer, France
Robarts RD, Zohary T, Waiser M, Yacobi YZ (1996) Bacterial abundance, biomass, and production in relation to phytoplankton biomass in the Levantine Basin of the southeastern Mediterranean Sea. Mar Ecol Prog Ser 137:273-281

Robinson AR (1983) Overview and summary of eddy science In: Robinson AR (ed) Eddies in marine science. SpringerVerlag, Berlin, p 3-15

Robinson AR, Golnaraghi M (1993) Circulation and dynamics of the Eastern Mediterranean Sea; quasi-synoptic datadriven simulations. Deep Sea Res II 40:1207-1246

Robinson AR, Hecht A, Pinardi $N$, Bishop J, Leslie WG, Rosentraub Z, Martiano AJ, Brenner S (1987) Small synoptic/mesoscale eddies and the energetic variability of the eastern Levantine basin. Nature 327:131-134

Robock A, Mao J (1992) Winter warming from large volcanic eruptions. Geophys Res Lett 12:2405-2408

Rowan KS (1989) Photosynthetic pigments of algae. Cambridge University Press

Sherr BF, Sherr EB, Pedros-Alias C (1989) Simultaneous measurement of bacterioplankton production and protozoan bacterivory in estuarine water. Mar Ecol Prog Ser 54: 209-219

Smetacek VS, Passow U (1990) Spring bloom initiation and Sverdrup's critical depth model. Limnol Oceanogr 35 : $228-234$

Stauber JL, Jeffrey SW (1988) Photosynthetic pigments in fifty-one species of marine diatoms. J Phycol 24:158-172

Sverdrup HU (1953) On conditions for the vernal blooming of phytoplankton. J Cons Int Explor Mer 18:287-295

Thingstad TF, Rassoulzadegan F (1995) Nutrient limitations, microbial food webs, and 'biological C-pump': suggested interactions in a p-limited Mediterranean. Mar Ecoi Prog Ser 117:299-306

Tranter DJ, Parker RR, Cresswell GR (1980) Are warm-core eddies unproductive? Nature 284:540-542

Yacobi YZ, Zohary T, Kress N, Hecht A, Robarts RD, Waiser M, Wood AM, Li WKW (1995) Chlorophyll distribution throughout the southeastern Mediterranean in relation to the physical structure of the water mass. J Mar Syst 6: $179-190$

Yentsch CS, Phinney DA (1985) Rotary motions and convection as a means of regulating primary production in warm core rings. J Geophys Res 90:3237-3248

Zapata M, Ayala AM, Franco JM, Garrido JL (1987) Separation of chlorophylls and their degradation products in marine phytoplankton by reverse-phase high-performance liquid chromatography. ('hromatographia 23:26-30

Submitted: October 29, 1997; Accepted: March 24, 1998 Proofs recelved from author(s): June 8, 1998 